\title{
The Student's Disposition Mathematical Profile By Using Probability Theory Module
}

\author{
1Rahmatya Nurmeidina, ${ }^{2}$ Ahmad Lazwardi, 3 Iin Ariyanti \\ 1,2,3Universitas Muhammadiyah Banjarmasin, Jalan Gubernur Sarkawi Barito Kuala, 05113363002 \\ e-mail: rahmatya.dina@gmail.com
}

\begin{abstract}
The purpose of this study is to describe the profile of the Mathematical Disposition of mathematics education study programs on the use of probability theory modules. This research is a qualitative descriptive study. The subjects of this study were mathematics education students who were taking probability theory lectures. Data collection techniques are mathematical disposition questionnaires, interviews and documentation. Data analysis techniques using document analysis techniques. The results showed that the mathematical disposition of Mathematics Education study program students on the use of the Theory of probability module were in the high and very high categories. The mathematical disposition of students is reviewed from every aspect of the indicator in the high category. This study shows a description of the Mathematical Disposition profile of Mathematics Education study program students on the use of probability theory modules covering aspects of selfconfidence, persistence, and perseverance, open or flexible thinking, interest, and curiosity, as well as monitoring and evaluating.
\end{abstract}

Keywords: Mathematical disposition; Module; Probability Theory

How to Cite: Nurmeidina, R., Lazwardi, A., \& Ariyanti, I. (2020). The Student's Disposition Mathematical Profile By Using Probability Theory Module. International Journal on Emerging Mathematics Education, 4(2), 73-80. http://dx.doi.org/10.12928/ijeme.v4i2.15625

\section{INTRODUCTION}

By the 2013 curriculum, the affective aspects of mathematical disposition such as valuing the use of mathematics in life, an attitude of curiosity, attention, and interest in learning mathematics, as well as a tenacious and confident attitude in solving mathematical problems are aspects that students must have after the learning process. Therefore students as professional teacher candidates must have mathematical disposition abilities. Mathematical disposition (Mahmudi, 2010b) strongly supports success in learning mathematics, a mathematical disposition is needed to not easily give up in facing problems, take responsibility in learning, and improve good work habits in mathematics. The ability of mathematical disposition is important for students to get accustomed to facing problems in life. Mathematical disposition is also one of the important standards that must be possessed by teachers according to the National Council of Teachers of Mathematics. Disposition is not just referring to attitude but a tendency to think and behave positively (Saija, 2012). Mathematical disposition is important for students to have because a positive disposition will help increase students' understanding of mathematical concepts (Kusmaryono \& Dwijanto, 2016) Thus the mathematical disposition is important for prospective mathematics teacher students to have. 
One of the courses in the mathematics education study program is the theory of probability. Probability theory (Ekawati et al., 2019) is a branch of mathematics concerned with probability, random phenomenon analysis. The main objects of probability theory are random variables, stochastic processes, and events: nondeterministic mathematical abstractions of events or measurable quantities that can be single events or develop over time in apparently random modes. Based on the experience of researchers at the time of taking the theory of probability courses it is known that many students have difficulty in understanding the concept material and questions both questions related to concepts and problem-solving problems. Students have difficulty understanding books used by lecturers because the books are still in English or translation books with discussions that are difficult for students to understand. Besides, if given the assignment to work on the questions, students give up easily if they find a difficult problem or not as exemplified, students do not study the material taught first, students only wait for the material given by lecturers and only learn from lecture notes in class. Based on research (Tinungki, 2018), it appears that the theory of probability courses for some students are still considered difficult and require a high level of understanding of mathematics, so students are often less sure that they can complete it. A learning method is needed that can improve students' mathematical disposition in probability theory lectures. Therefore, the lecturer makes a module. The learning objectives use modules to facilitate students in studying course material, increase curiosity and student interest in learning. Thus it is hoped that after using the module students can better understand the probability theory learning. Based on our previous research (Nurmeidina et al., 2020) on learning in higher education, lecturers play an important role in providing facilities or conditioning lectures with the right method, one of them is by making learning modules. The research resulted in a valid, practical, and effective probability theory module. Another research related to mathematical dispositions in higher education learning is research on the profile of mathematical dispositions for mathematics students in the integral calculus course (Sugiyanti et al., 2017). The mathematical disposition profile from the student of mathematic education of university of PGRI Semarang on integral calculus lecture consists of : self confidence, sel efficacy, curiousity, deligence, flexibility and reflective. Research related to mathematical disposition profiles is important to do to find out in detail the aspects of mathematical dispositions that develop in lectures using modules. Thus, research on mathematical disposition profiles is carried out with renewal in the subject which is the theory of opportunity with the specificity of using modules as a continuation of previous research.

So, after learning to use the probability theory module is finished, then it will be seen how the mathematical disposition of mathematical education students after using the module. Thus, the purpose of this study was to determine the mathematical disposition profile of mathematics education students in University of Muhammadiyah Banjarmasin using the probability theory module.

\section{RESEARCH METHOD}

This research is qualitative descriptive research. The subjects in this study were 9 students of the Mathematics Education Faculty of Mathematics and Natural Sciences University of Muhammadiyah Banjarmasin University who were taking probability theory courses. Research instruments in the form of questionnaires and interview sheets. The mathematical disposition questionnaire consists of 5 indicators of mathematical disposition namely self-confidence, persistence and perseverance, open

IJEME, Vol. 4, No. 2, September 2020, 73-80. 
and flexible thinking, interests and curiosity, tendency to monitor the process of thinking and one's performance (monitor and evaluate) (Mahmudi, 2010a). The five indicators are contained in 28 items of positive and negative statements, which can then be seen in table 1 . The questionnaire that was compiled was then validated by a mathematics education lecturer. The validator provides advice and input. The comments and suggestions for improvement of the validator on the mathematical disposition questionnaire are as follows to correct words that are redundant and ambiguous and be consistent in word selection. The validator also provides comments and corrections to the item questionnaire items that need to be revised. Revision of questionnaire items in the form of the addition of abbreviations, inconsistent revisions of words and simplification of sentences that are too long and inefficient.

Table 1. Indicators on the Mathematical Disposition Questionnaire

\begin{tabular}{lll}
\hline No & Indicator & Number statement \\
\hline 1 & Confident & $1(+), 2(+), 3(+), 4(-), 5(-), 6(-)$ \\
2 & Persistence \& perseverence & $7(+), 8(-), 9(-), 10(+), 11(+), 12(-)$ \\
3 & Open \& Flexible thinking & $13(+), 14(+), 15(-)$ \\
4 & Interests \& curiosity & $16(+), 17(+), 18(+), 19(+), 20(+), 21(-)$ \\
5 & Monitor \& evaluate & $22(+), 23(+), 24(+), 25(-), 26(+), 27(+), 28(-)$
\end{tabular}

After the research instruments are prepared and go through a validation process. Students fill out a questionnaire after completing the learning process using the probability theory module. Then the questionnaire results were analyzed. The data analysis technique is as follows: mathematical disposition questionnaire data analysis with 5 categories of choices, namely by grouping data based on product qualifications to be assessed. Based on data that has been grouped and then carried out calculations to obtain an average value. The average score obtained is then entered into a qualitative category as contained in table 1 which was adapted from the qualitative category of Azwar data interpretation (Azwar, 2015). Table 2 shows the qualitative categories of data interpretation for the overall mathematical disposition questionnaire.

Table 2. Qualitative Categories of Mathematical Disposition Questionnaire

\begin{tabular}{ll}
\hline Quantitative Score Range & $\begin{array}{l}\text { Qualitative } \\
\text { Categories }\end{array}$ \\
\hline $91<\bar{x}$ & Very high \\
$77<\bar{x} \leq 91$ & high \\
$63<\bar{x} \leq 77$ & Average \\
$49<\bar{x} \leq 63$ & Low \\
$\bar{x} \leq 49$ & Very low \\
\hline
\end{tabular}

Table 3 shows every aspect of the mathematical disposition questionnaire indicator. After the questionnaire data has been analyzed. Then the researchers conducted interviews with students. Interviews were conducted to clarify again the results of the questionnaire. 
Table 3. Qualitative Categories of Mathematical Disposition Questionnaire For each aspect (Azwar, 2015)

\begin{tabular}{cccccl}
\hline $\begin{array}{c}\text { Range of Score } \\
\text { Confident }\end{array}$ & $\begin{array}{c}\text { Persistence \& } \\
\text { perseverence }\end{array}$ & $\begin{array}{c}\text { Open \& Flexible } \\
\text { thinking }\end{array}$ & $\begin{array}{c}\text { categories } \\
\text { Interests \& } \\
\text { curiosity }\end{array}$ & $\begin{array}{c}\text { Monitor \& } \\
\text { evaluate }\end{array}$ & \\
\hline $19,5<\bar{x}$ & $19,5<\bar{x}$ & $9,995<\bar{x}$ & $19,5<\bar{x}$ & $22,75<\bar{x}$ & Very high \\
$16,5<\bar{x} \leq 19,5$ & $16,5<\bar{x} \leq 19,5$ & $8,665<\bar{x} \leq 9,995$ & $16,5<\bar{x} \leq 19,5$ & $19,25<\bar{x} \leq 22,75$ & High \\
$13,5<\bar{x} \leq 16,5$ & $13,5<\bar{x} \leq 16,5$ & $7,335<\bar{x} \leq 8,665$ & $13,5<\bar{x} \leq 16,5$ & $15,75<\bar{x} \leq 19,25$ & Middle \\
$10,5<\bar{x} \leq 13,5$ & $10,5<\bar{x} \leq 13,5$ & $6,005<\bar{x} \leq 7,335$ & $10,5<\bar{x} \leq 13,5$ & $12,25<\bar{x} \leq 15,75$ & Low \\
$<\quad \bar{x} \leq 10,5$ & $\bar{x} \leq 10,5$ & $\bar{x} \leq, 005$ & $\bar{x} \leq 10,5$ & $\bar{x} \leq 12,25$ & Very low \\
\hline
\end{tabular}

\section{RESULTS AND DISCUSSION}

The all result of the students' mathematical disposition shows on Figure 1. Mathematical disposition Diagram. The figure shows the student's disposition after uses probability theory module on high category and very high.

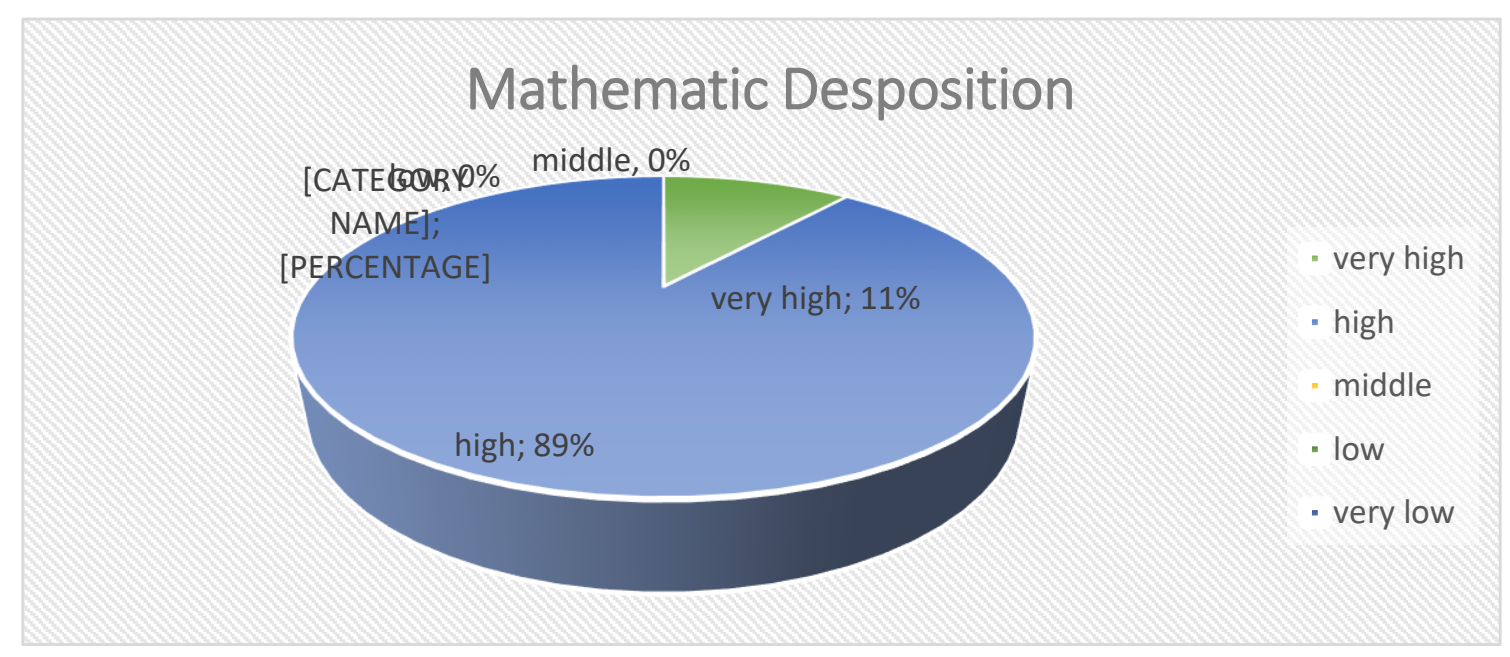

Figure 1. Pie chart of the students' mathematical disposition

The students' mathematical disposition after using probability theory module is on high category and very high, this is appropriate with the research (Fitri et al., 2015) which shows that the lecture uses module, it can increase the student's learning activity. One of learning activity indicator is emotional activity, such as having interest and spirit. Interest and spirit are mathematical disposition indicator. The result of mathematical disposition questionnaire for each category can be seen on Table 4 .

Table 4. The observing of the Students' Mathematical Disposition from each indicator

\begin{tabular}{llll}
\hline No & Indicator & Score & Category \\
\hline 1 & Self confident & 18,22 & High \\
2 & Persevere \& diligent & 18,11 & High \\
3 & Open minded dan flexsible & 9,33 & High \\
\hline
\end{tabular}

IJEME, Vol. 4, No. 2, September 2020, 73-80. 


\begin{tabular}{llll}
\hline 4 & Interest dan curious & 16,89 & High \\
5 & Monitor dan evaluation & 22,11 & High
\end{tabular}

Table 4 shows that all of the mathematical disposition indicators from the students of mathematic education is high. The profile of mathematical disposition from the students of mathematic education study program on the using of probability theory module, includes of self confident aspect, persevere and diligent, open minded or flexible, interest and curious, monitoring and evaluating.

Each mathematical disposition indicator consists of some questions. Each question will be analyzed based on the student's questionnaire answer and interviewed confirmation. There are 6 statements of self confident indicator, 5 statements are in high category and 1 statement is very high category. But if we observe from each statement, the statement which gets score 1 or 2 from the student, such as number $2,5,6$. When the student filled in the mathematical disposition questionnaire, 2 students answered that they disagreed and 7 students answered that they agreed for the statement number 2 "I believe that I am able to do the lecture assignment which is given". After doing the interview with the student who answered disagree with that statement. They explained that they answered disagree to that statement because it is not all of the assignment can be understood directly, but even they don't understand with the assignment, they ask to their friend who understand persistently.

On the statement number 5 "I am shame if the other people know if I get low score". There were 3 students answered agree. The result of interview shows that the student is shame if the other people know if they get low score but it is just on short time, next they are motivated to increase that their score. On the statement "I am afraid if my lack in this lecture is known by other people". There was 1 student who answered agree, 7 students were disagree. The result of the interview was shown that the students try to cover their lack in probability theory lecture even they don't want the other people know about it, they are still try to ask and repair to their lack.

There are 6 statement on persevere and diligent. All of the statements are on high category. But if we observe from each statement, There were some statement which got score 1 or 2 from the student, such as the statement number 8, 9, 10 .

When the students answered the questionnaire, 2 students answered disagree and 7 students answered agree on the statement "I only study probability theory when I have examination or learning a night before the examination", and each 1 student answered disagree with the statement "I learn probability theory at the campus only" and "even there is no probability theory assignment, I review again the material which has been learned when there is a lecture at the class". After doing interview, they answered disagree with those statements, because they think that they don't have time and opportunity to learn probability theory lecture. They will learn if there is no examination and no assignment. It is because there are a lot of other lecture assignments that must be submitted.

There are 3 indicator statements on open minded or flexible. All of the questions are on high category. But there were 2 students who answered disagree on the statement "I believe that to change the method of answering the test from what the lecturer explained before or written on the module can cause the answer wrong". The result of the interview showed that the student only rely on the things which the lecturer explained before. They never try to use the other method except the method which their lecture explained. 
There are 6 statements on interest and curious category. There are 5 statements on high category, and 1 statement on low category. That statement is "I prefer to do probability theory test by counting with using the formula directly than the test which needs analyzing ". The result of the interview showed that the students prefer to do the test which using the formula directly than the test which needs analyzing to answer. But if they must to do that test, they try to do that test maximally.

But, to make easier, they prefer to do the test which use the formula first. Beside that, there is statement which was answered disagree by the students. It is "I learn the other reference lecture book which doesn't be used lecturer when teaching ". The result of the interview showed that the student thinks that it is enough to learn from the module which is given by the lecturer. Beside that 1 student answered agree on the statement " The students do the test if there is the assignment only" and don't agree on the statement "I have a challenge to do the difficult probability theory". The result of the interview showed that the same as the question before, that there are a lot of other assignments which make the students do the assignment only and they feel if they don't have time to practice the test individually.

The last, there are 7 statements on monitor and evaluation category. There are 6 statements on high category and 1 statement is on very high category. All of the students answered agree on the positive statement and disagree on the negative category. The result of the interview showed that 8 students claimed to get score A and 1 student claimed to get score B. The students understand their lack from evaluating of middle test score of probability theory and try to repair. It is supposed to get better score on their final test.

We know from this research that the student mathematical disposition is on high category on each aspect. With the high disposition, It is hoped that the students have high understanding on the material of probability theory. It is appropriate with (Kesumawati, 2015). The orientation of mathematical disposition through the study is exploration, finding out, understanding, application, and doing the values that is present on teaching learning process. We can use all of them to increase the student's mathematical understanding. Furthermore, mathematical dispositions will affect learning outcomes (Lestari et al., 2016) and differences in mathematical abilities will result in differences in mathematical dispositions and learning outcomes (Beyers, 2012).

The result of using this modules that is can improve students'mathematical dispositions is relevant to research which states that the use of learning media with a contextual approach can improve students' mathematical dispositions (Chotimah et al., 2018). In this case, the module is one of the learning media with a contextual approach because the material in the module is also related to the real context. Besides, it is also appropriate to Devesh and Nasseri's research which states that learning mathematics using modules is very effective for students (Devesh \& Nasseri, 2014).

Generally, If we connect with the using of probability theory module, the student fells that it is really helpful and makes them to be interested in learning probability theory first, even though there is no examination or assignment. Those above are accordance with external factors that are influence in learning (Marleni, 2016). That is the method which is used by the teacher in teaching. In this case, the lecturer teaches using the module to make easier the student to learn. The students will get easier to learn both of in the lecture or not in the lecture. Based on the research (Purwasih \& Bernad, 2018) the disposition mathematical of mathematic education student used Discourse Multi Representative (DMR) was better than conventional learning. It is

IJEME, Vol. 4, No. 2, September 2020, 73-80. 
suggested that supposed to DMR learning is more effective, it is better to prepare good facility, example module. So it can be continued the research by using DMR learning and supporting by the module.

\section{CONCLUSION}

Mathematical disposition for the student of mathematic education study program on using probability theory module is on high category and very high. The student mathematical disposition is observed from each indicator is on high category. The profile mathematical disposition in this research include of : self confident aspect, preserve and diligent, open minded and flexible, interest and curious and also monitoring and evaluation.

Based on the questionnaire result, the researchers did interview to the students who answer with the score 1 and 2 to clarify and to make clear their answer. The conclusion is even though they haven't understood yet with the assignment, the students ask persistently with their friend who understand. The students try to cover their lack ness in probability theory lecture, even though they don't wont anybody knows. The students try to ask persistently and repair their lack. The student has had the target in the lecture. It gets score A. All of the students have commitment to make the middle test score as evaluation supposed to get final test score better. In other aspect, the student is only focus on the material and the example to do the exercise which is written on the module and prefer to do the test by applying the formula directly than the test with problem solving. But if it is needed to do the test with problem solving, they try to finish it persistently. Beside that there are external factor which is influence, such as some other lecture assignments which must be submitted. So the students feel that they don't have enough time to learn first or to do the test persistently, even there is no assignment. Based on the explanation above, the researchers suggest that there must be next research about experiment of the effectiveness of probability theory module to probability theory learning to increase the student mechanical disposition. Beside that, It can be done the research about the applying of MultiRepresentation Discourse (DMR) learning by synergy with this probability theory module.

\section{REFERENCES}

Azwar, S. (2015). Tes Prestasi, Fungsi dan Pengembangan Pengukuran Prestasi Belajar. In Pustaka Pelajar: Vol. Cetakan XV.

Beyers, J. E. R. (2012). An examination of the relationship between prospective teachers' dispositions and achievement in a mathematics content course for elementary education majors. SAGE Open, 2(4), 1-15.

Chotimah, S., Bernard, M., \& Wulandari, S. M. (2018). Contextual approach using VBA learning media to improve students' mathematical displacement and disposition ability. Journal of Physics: Conference Series, 948(1), 0-10.

Devesh, S., \& Nasseri, D. A. L. (2014). Effectiveness of Mathematics Module in Foundation Programme in Majan College. International Journal of Emerging Engineering Research and Technology, 2(1), 1-7.

Ekawati, T., Anggoro, B. S., \& Komarudin. (2019). Pengembangan Modul Pembelajaran Matematika pada materi Statistika terintegrasi NIlai-nilai 
Keislaman. Aksioma, Jurnal Pendidikan Matematika FKIP Universitas Muhammadiyah Metro, 8(1), 184-192.

Fitri, D. Y., Septia, T., \& Yunita, A. (2015). Pengembangan Modul Kalkulus 2 Pada Program Studi Pendidikan Matematika Di Stkip Pgri Sumatera Barat. Jurnal Pelangi, 6(1).

Kesumawati, N. (2015). The Basic Ability on Basic Statistics and Mathematical Disposition of the Second Semester Students of Mathematics Education PGRI University of Palembang. Proceeding of International Conference On Research, Implementation And Education Of Mathematics And Sciences, Proceeding of International Conference On Research, Implementation And Education of Mathematics And Sciences 2015, Yogyakarta State University, May, 17-19.

Kusmaryono, I., \& Dwijanto, D. (2016). Peranan Representasi Dan Disposisi Matematis Siswa Terhadap Peningkatan Mathematical Power. JIPMat, 1(1), 1928.

Lestari, L. A., Suharto, S., \& Fatahillah, A. (2016). Analisis Pengaruh Disposisi Matematis terhadap Hasil Belajar Materi Integral Tak Tentu Siswa Kelas XII IPA 2 SMAN 4 Jember. Jurnal Edukasi, 3(1), 40.

Mahmudi, A. (2010a). Pengaruh Pembelajaran dengan strategi MHM berbasis masalah terhadap Kemampuan berpikir Kreatif, kemampuan Pemecahan masalah, dan Disposisi matematis, serta persepsi terhadap Kreativitas. Universitas Pendidikan Indonesia.

Mahmudi, A. (2010b). Tinjauan Asosiasi antara Kemampuan Pemecahan Masalah Matematis dan Disposisi Matematis. Makalah Disajikan Pada Seminar Nasional Pendidikan Matematika FMIPA UNY, 17(April), 1-11.

Marleni, L. (2016). Faktor-faktor yang Mempengaruhi Minat Belajar. Journal Cendekia: Jurnal Pendidikan Matematika, 1(1), 149-159.

Nurmeidina, R., Lazwardi, A., \& Ariyanti, I. (2020). Pengembangan Modul Teori Peluang untuk Meningkatkan Hasil Belajar dan Disposisi Matematis. 9(2), 440450.

Purwasih, R., \& Bernad, M. (2018). Pembelajaran diskursus multi representasi terhadap peningkatan kemampuan komunikasi dan disposisi matematis mahasiswa Learning multi discourse representation to enhance students communication and their mathematical disposition. Jurnal Riset Pendidikan Matematika, 5(1), 43-52.

Saija, L. M. (2012). Analyzing The Mathematical Disposition and ITS. Infinity Journal, $1(2), 148-152$.

Sugiyanti, S., Prasetyowati, D., \& Kartinah, K. (2017). Profil Disposisi Matematis Mahasiswa Program Studi Pendidikan Matematika Universitas Pgri Semarang Pada Mata Kuliah Kalkulus Integral. JIPMat, 2(2).

Tinungki, G. M. (2018). Meningkatkan Keyakinan Diri Mahasiswa Menyelesaikan Tugas-tugas pada Mata Kuliah Teori Peluang. KNPMP III 2018, 380-387. 